\title{
Kırşehir (Akpınar) Bölgesi Lösititlerinin Kaplama Taşı Olarak Kullanılabilirliği
}

\author{
Usability of Lösitites of Kırşehir (Akpınar) Region as Covering Stone
}

\author{
Zeynel BAŞIBÜYÜK ${ }^{* 1, a}$, Gökhan EKİNCİOĞLU ${ }^{2, b}$ \\ ${ }^{I}$ Jeoloji Mühendisliği Bölümü, Mühendislik Mimarlık Fakültesi, Ahi Evran Üniversitesi, Kırşehir, Türkiye \\ ${ }^{2}$ Madencilik ve Maden Çıkarma Bölümü, Kaman MY O, Ahi Evran Üniversitesi, Kırşehir, Türkiye
}

\author{
• Geliş tarihi / Received: 20.02.2019 • • Düzeltilerek geliş tarihi / Received in revised form: 27.05.2019 • Kabul tarihi / Accepted: 21.06 .2019
}

\begin{abstract}
$\ddot{O} z$
Lösitit, dünyada nadir olarak gözlenen foidolit kaya grubu içerisinde tanımlanan bir magmatik kayaçtır. Bu çalışma kapsamında Kırşehir ili kaman ilçesi İsa Hocalı köyünün 1 km kuzey batısında bulunan lösitit kayacının yayılımı, renk ve doku devamlılığı, mineralojik-petrografik, fiziksel-mekanik özellikleri belirlenmiş ve jeokimyasal analizleri yapılmıştır. Elde edilen verilere göre TS 6234 standardına göre lösititin zemin ve duvar kaplaması olarak kullanılabilir olduğu belirlenmiştir. Ülkemizde üretimi gerçekleştirilen granitler çoğunlukla gri renklidir. Çalışma alanındaki lösititlerin koyu rengi ve kendine has leopar dokusundan dolayı "Kırşehir Leopar" ismi ile ticari değere sahip olabileceği öngörülmektedir. Kırşehir bölgesi lösititlerinin üretime kazandırılması ile doğal taş sektör ürün portföyünde farklı renk ve dokuda kayaç kazandırılarak hem bölge, hem de ülke ekonomisine katkı sunacağı düşünülmektedir.
\end{abstract}

Anahtar kelimeler: Doğal Taş, Fiziksel ve Mekanik Özellikler, Kırşehir Leopar, Lösit

\begin{abstract}
Leucitits is a magmatic rock, which is rarely found in the foidolite rock group. Leucitits rock is located $1 \mathrm{~km}$ north-west of Isa Hocall village in the Kaman district of Kirsehir province. In this study, the distribution of leucite, color and texture continuity, mineralogical-petrographical and physical-mechanical properties were determined and geochemical analyzes were performed. According to the data obtained, it has been identified that leucitite can be used as floor and wall covering according to TS 6234 standard. Granites produced in our country are mostly gray colored. The Leucitite in the study area has a dark color and unique leopard tissue. Therefore, it is predicted that it may have commercial value with the name" Kirşehir Leopar". By bringing the leucites of Kirşehir region into production, it is thought that the natural stone sector will contribute to the economy of the region and the country by adding rock in different color and texture in the product portfolio.
\end{abstract}

Keywords: Natural Stone, Physical and Mechanical Properties, Kirsehir Leopard, Leucite

\footnotetext{
${ }^{*}$ ZZeynel BAȘIBÜYÜK; zbasibuyuk@ahievran.edu.tr; Tel: (0386) 28038 06; orcid.org/0000-0003-2845-148X

borcid.org/0000-0001-9377-6817
} 


\section{Giriş}

Lösitit kayacı doğal taş sektöründe ticari isim olarak "Granit" olarak adlandırılan kesilip parlatılabilen magmatik derinlik kayaçları içerisinde bulunur. Granitler estetik görünümleri ve atmosferik şartlarda bozunmaya karş1 gösterdiği direnç nedeni ile yapı sektöründe zemin ve duvar kaplaması olarak birçok alanda kullanılmaktadır. Ülkemiz granit sahalarını Batı Anadolu Granitleri, Orta Anadolu Granitleri ve Kuzeydoğu Anadolu Granitleri şeklinde ana hatlarıyla gruplandırabilir (Taşlıgil ve Şahin, 2016). Türkiye'deki önemli granit rezervleri Ordu, Rize, Trabzon, Balıkesir, Kırklareli, Kırşehir, Bolu, İzmit, Çanakkale ve İzmir'de bulunmaktadır. Parlak görünümü ve dayanıklılığ ile genellikle gelişmiş ülkelerde tercih edilen granitin kullanımı son zamanlarda ülkemizde de yaygınlaşmaya başlamıştır (TCTB, 2018).

Ülkemizde yaygın olarak üretimi gerçekleştirilen ve ticari olarak değerlendirilen granitler, Aksaray Yaylak, Bulancak Füme, Bergama Gri ve Hisar Gri'dir. Bahsi geçen ticari değere sahip ülkemiz granitleri gri renk tonlarında karşımıza çıkmakta olup renk çeşitliliği bakımından oldukça sınırlı kalmaktadır. $\mathrm{Bu}$ nedenle ülkemiz granit ticari potansiyelinin artırılması noktasında renk ve doku çeşitliliğinin arttırılması önem arz etmektedir. Doğada nadir olarak gözlenen feldispatoidli kayaçlardan, foidolit kaya grubu içerisinde tanımlanan lösitit kayacı, koyu renk tonu ve leopar benzeri dokusu nedeni ile oldukça dikkat çekici bir doğal taştır.

$\mathrm{Bu}$ çalışmanın amacı çalışma sahasındaki kendine özgü farklı doku ve renk bileşimine sahip olan lösitit kayacının, arazideki durumunu belirlemek, mineralojik-petrografik ve fiziko-mekanik özelliklerin belirlenmesi sonucunda, doğal taş sektörüne kazandırmak ve böylece hem bölge hem de ülke ekonomisine katkı sunabilmektir.

\section{Materyal ve Yöntem}

İnceleme alanındaki lösititlerin yayılımları, renk ve doku devamlılıkları ile diğer kayaçlarla olan dokanak ilişkilerinin belirlenmesi amacı ile jeolojik arazi çalışmaları yapılmıştır. Yüzey kaplama taşı olarak işletilebilir potansiyeline sahip olduğu düşünülen 3 farklı lokasyondan, lösititleri temsilen kimyasal analiz, ince kesit incelemeleri ve kayaçların fiziko-mekanik özelliklerinin belirlenmesi amaciyla altere olmayan seviyelerden örnekler alınmıştır. Lösititin ana element analizi XRF yöntemi ile
Kütahya Dumlupınar Üniversitesi ILTEM Laboratuvarında gerçekleştirilmiştir. Mineralojikpetrografik özelliklerin tespit edilmesi amaciyla alınan örneklerden Kırşehir Ahi Evran Üniversitesi Mühendislik Mimarlık Fakültesi Jeoloji Mühendisliği Bölümü İnce Kesit Laboratuvarı'nda ince kesitler hazırlanmıştır. Araziden alınan numuneler özgül ağırlığı, birim hacim ağırlı̆̆ı, görünür porozitesi, toplam porozitesi, böhme yüzey aşınması, Shore sertlik değerleri ve basınç dayanımı gibi fiziksel ve mekanik özelliklerin TS EN 13755 (2014), TS EN 14157 (2017), TS EN 1926 (2013), ISRM (2007)'e göre belirlenmesi amaciyla Ahi Evran Üniversitesi Kaman Meslek Yüksekokulu Madencilik ve Maden Çıkarma Bölümü Taş Analiz Laboratuvarı'nda belirli ebatlarda kesilmiş ve analizler gerçekleştirilmiştir. Elde edilen veriler sonucunda Kırşehir Leopar numunelerinin TS 6234 standardında göre yüzey ve duvar kaplaması olarak kullanılabilirliği araştırılmıştır.

\section{Jeoloji}

İnceleme sahasındaki en yaşlı seviyeyi şist, gnays, amfibolit ve mermerlerden oluşan Paleozoyik yaşlı Orta Anadolu Metamorfitleri oluşturmaktadır. Seymen (1981), yaptığı çalışmada birimi 3 formasyona ayırmıştır. Bunlar yaşlıdan gence doğru, Kalkanlıda $\breve{g}$, Tamada $\breve{g}$ ve Bozçaldağ formasyonlarıdır. Üst Kretasede dasitriyolit-riyodasit bileşimli Orta Anadolu Volkanitleri ve Üst Kretase-Paleosen yaşlı granitsiyenit-monzonit bileşimli Orta Anadolu Granitoyidleri kendinden yaşlı birimleri keserek yerleşmişlerdir. Tüm bu birimleri Alt-Orta EosenKuvaterner yaşlı sedimanter birimler uyumsuzlukla örtmektedir (Şekil 1).

Bölge ve yakın çevresinde bulunan magmatik kayaçlar, Erler ve Bayhan (1995) tarafindan "Orta Anadolu Granitoyidleri” olarak tanımlanmıştır. Granit, siyenit ve monzonit bileşimine sahip bu kayaçlar Üst Kretase-Paleosen yaşlıdır (Otlu, 1998; Boztuğ vd., 2009). Orta Anadolu Metamorfitleri ve Orta Anadolu Granitoyidleri, Eosen - Kuvaterner yaşlı denizel ve karasal kaya birimleri tarafından örtülmektedir. Çakıltaşı, kumtaş1, silttaş1, kiltaş1, kireçtaş1 ve yer yer tüf, jipsli seviyelerin ardalanmasından oluşan bu birimler, yaşlıdan gence doğru, Baraklı Formasyonu, Arzılar Kireçtaşı Üyesi, Meşeköy Formasyonu, Kozaklı Kireçtaşı Üyesi, Kızılırmak Formasyonu, traverten ve alüvyon olarak tanımlanmıştır (Kara ve Dönmez, 1990; Otlu ve Boztuğ, 1998; Boztuğ vd., 2009). 


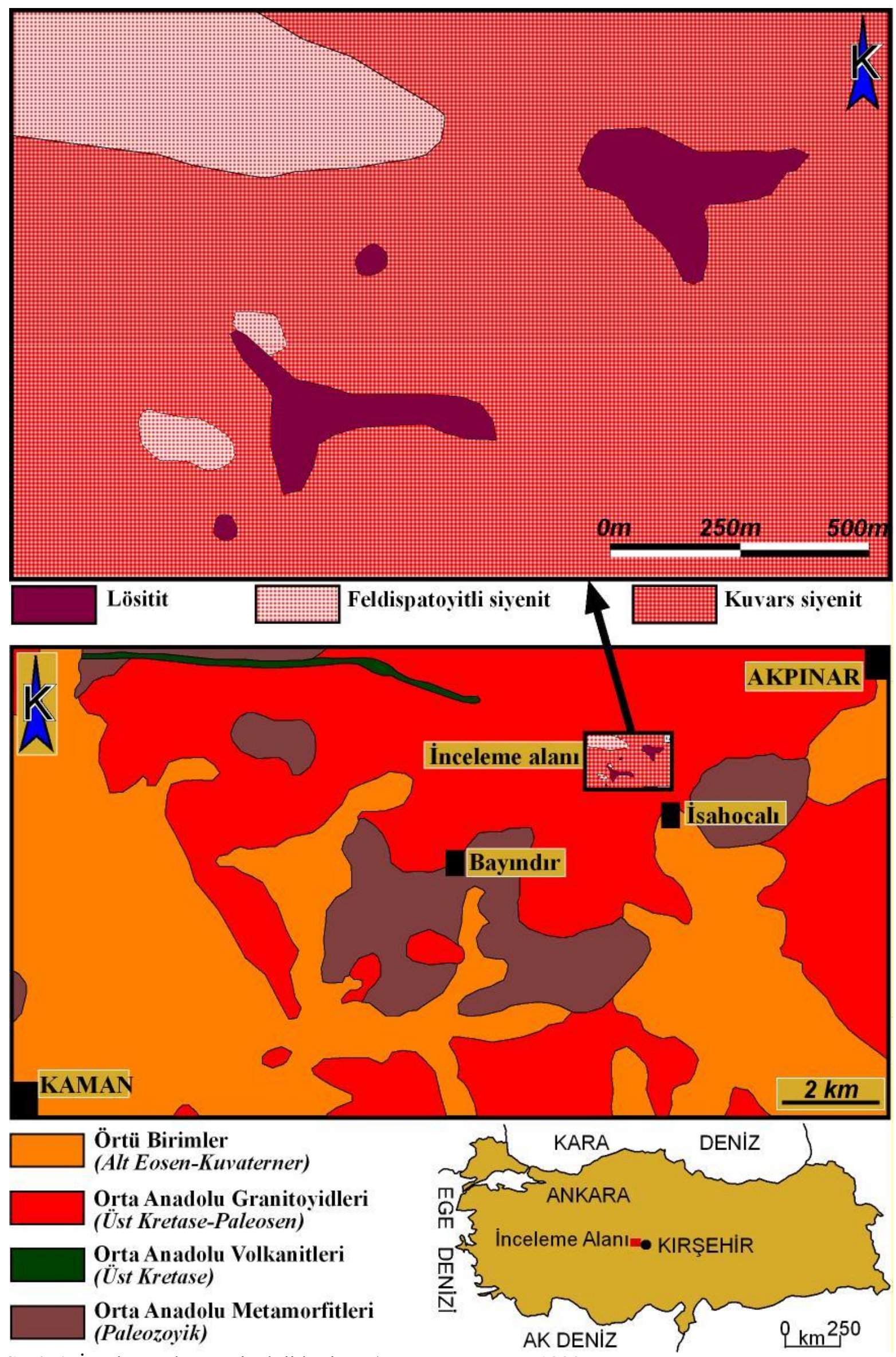

Şekil 1. İnceleme alanının jeoloji haritası (Kara ve Dönmez, 1990) 


\subsection{Arazi Çalışmaları}

Orta Anadolu Granitoyidleri içerisinde bulunan lösitit inceleme sahasında KD-GB yönünde uzanan bir hat boyunca yayılım göstermekte ve genellikle bölgedeki en üst topoğrafyalarda yüzlek vermektedir. Birim sert, tıkız ve masif bir yapıya sahiptir ve altere olmamıştır. Bölgede iki hakim seleksiyona sahip olarak gözlenmiştir. İnceleme sahasının GB tarafinda mafik mineral içeriğindeki zenginleşmeden dolay1 daha koyu bir tona sahipken diğer lokasyonlarda mafik mineral içeriğindeki azalma nedeni ile daha açık bir tona sahiptir (Şekil 2). Yüzeysel ve hidrotermal alterasyondan pek fazla etkilenmemesi kayacin blok verimini arttırıcı bir etken oluştururken, birim içerisinde yer yer gözlenen soğuma çatlakları (Şekil 3) blok verimini olumsuz etkileyici bir neden olarak açığa çıkmaktadır.

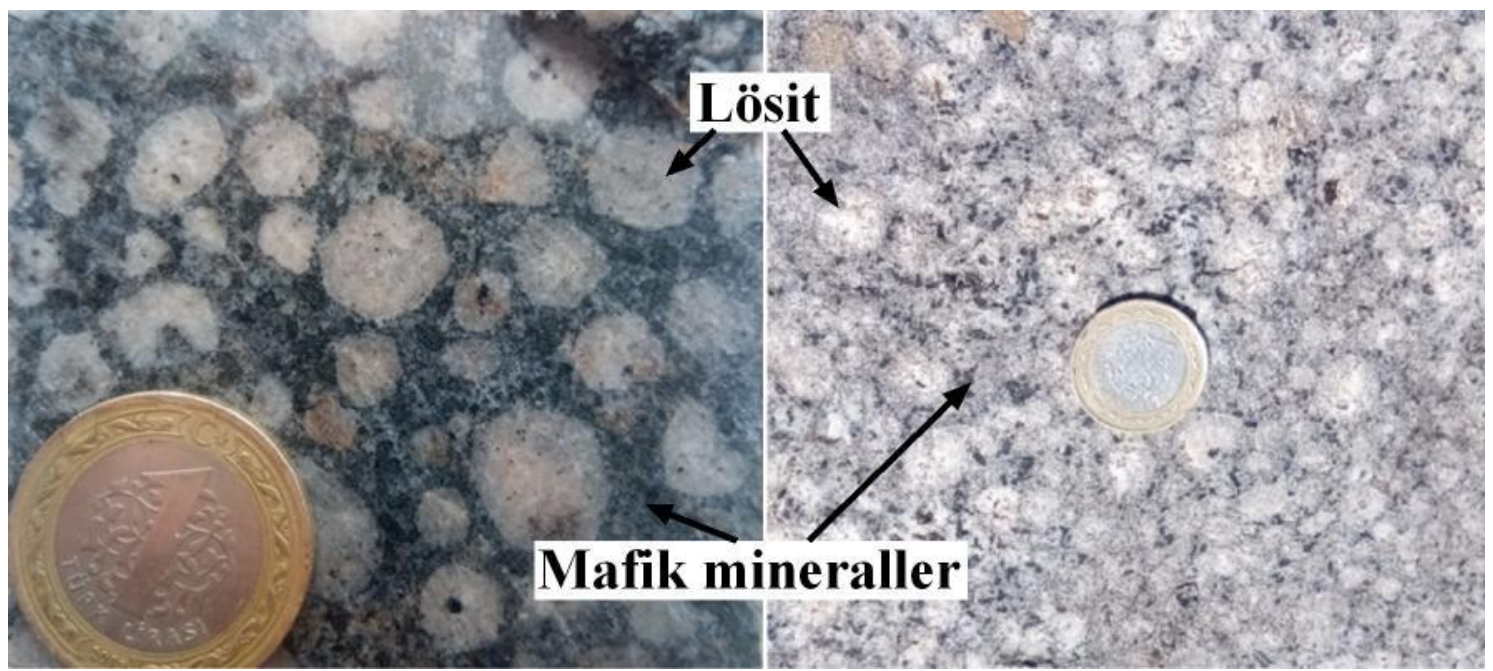

Şekil 2. Lösititlerde mafik mineral içeriğine bağlı olarak gözlenen farklı renk seleksiyonları.

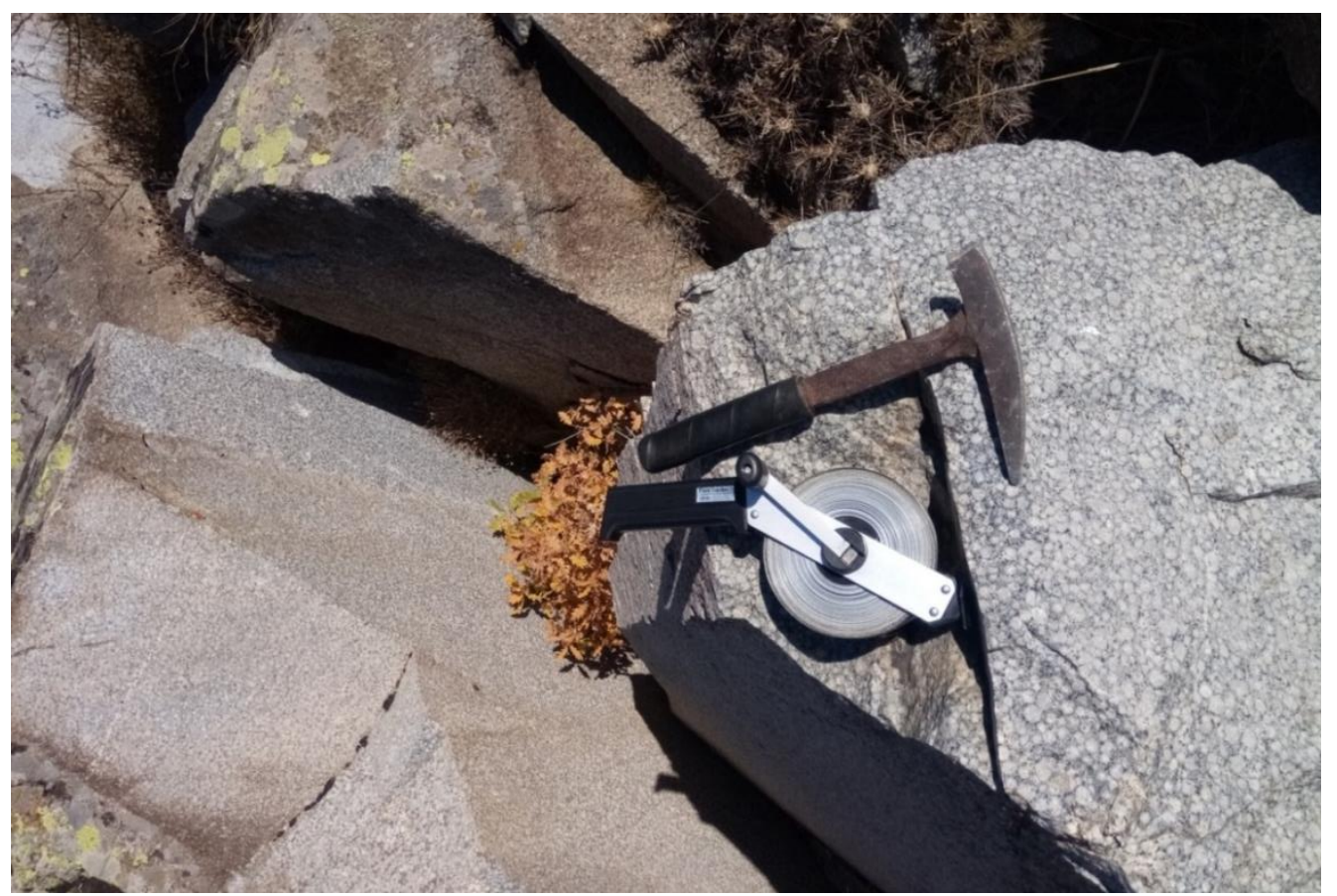

Şekil 3. Lösititlerde gözlenen soğuma çatlakları.

Birim inceleme sahası içerisinde pembemsi kahve renkli kuvars siyenit (Şekil 4.a) ya da yer yer feldispatoyitli siyenit (Şekil 4.b) dokanağında özşekilsiz oval yayılımlar şeklinde yüzlek sunmaktadır. Yüzeyde ayrı patatesler şeklinde yan yana gözlenen bu seviyelerin derinlerde birleșerek büyük bir kütle oluşturma ihtimali oldukça yüksektir. Bunun belirlenmesi bölgede yapılacak sondaj verilerinin değerlendirilmesi ile ortaya çıkartılabilir. 

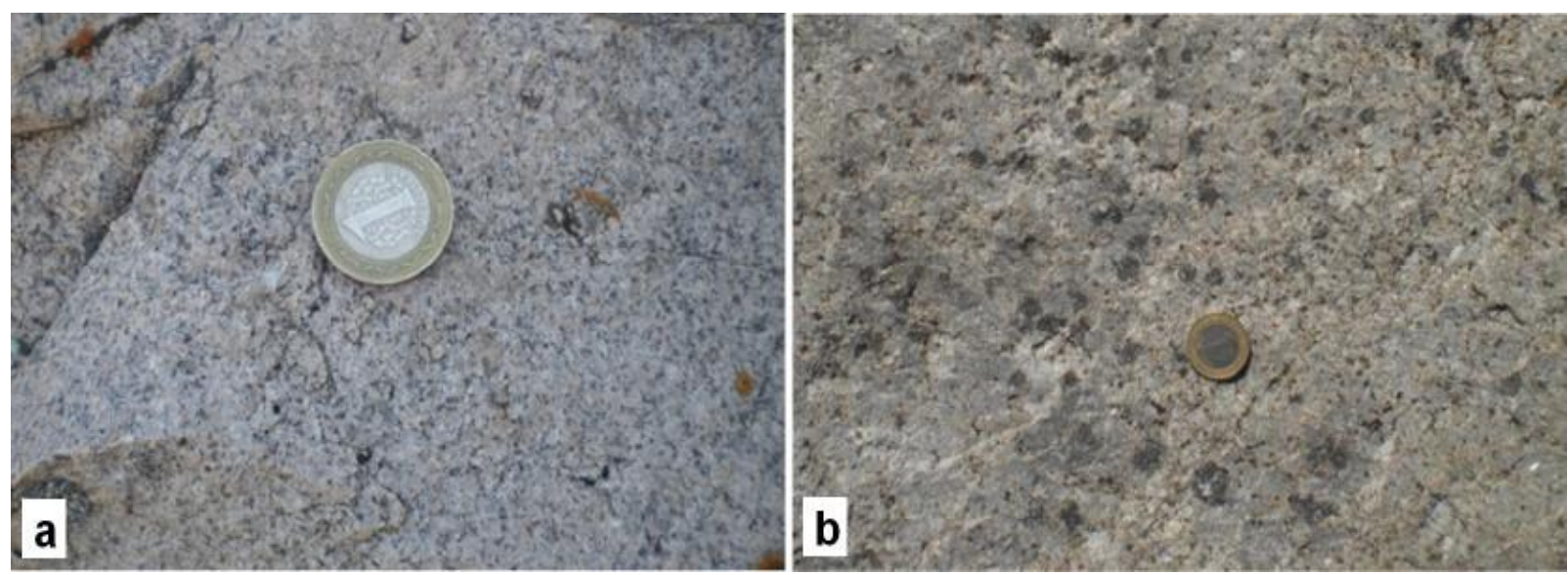

Şekil 4. Lösititlerle dokanak halinde bulunan kuvars siyenit (a) ve feldispatoyidli siyenit (b).

\section{Laboratuvar Çalışmaları}

Çalışma alanı içerisinde renk ve doku anlamında görselliği bulunan ve üretim potansiyeline sahip bölgelerden mümkün oluğunca alterasyona maruz kalmayan, arazi yüzeyinden alınan Kırşehir Leopar kayacının laboratuvar ortamında öncelikle kimyasal içeriğinin belirlenmesi amaciyla Kütahya Dumlupınar Üniversitesi İLTEM Laboratuvarında kimyasal analizi yapılmıştır. Kırşehir Ahi Evran Üniversitesi mineraloji petrografi laboratuvarında kayacın mineralojik ve petrografik özellikleri belirlenerek kayaç tanımlama işlemleri gerçekleştirilmiştir. Daha sonrasında ise araziden alınan örnekler TS EN ve ISRM standartları kapsamında gerekli ebatlara getirilmiş olup ilgili standartlar çerçevesinde kayacın fiziksel ve mekanik özellikleri Kırşehir Ahi Evran Üniversitesi Kaman Meslek yüksekokulu Kaya Mekaniği laboratuvarında belirlenmiştir.

\subsection{Kimyasal Analiz}

Kimyasal analizler için çalı̧smada kullanılan kayaç öncelikle KAEÜ Kaman Meslek Yüksekokulu Kaya Mekaniği Laboratuarındaki çeneli kırıcıda kırılmış ve bilyalı değirmende ögütülerek kimyasal analiz boyutu olan 100 $\mu \mathrm{m}$ 'nin altına indirilmiştir. Öğütülmüş numunenin kimyasal analizi Kütahya Dumlupınar Üniversitesi İLTEM Laboratuvarında kimyasal analizi yapılmıştır. Analiz sonuçları Tablo 1'de verilmiştir.

\subsection{Mineralojik Petrografik Analiz}

Lösit, potasyumca zengin, silisçe-fakir bir magmadan türemiş yüzeyde veya yüzeye yakın ortamlarda katılaşan çok tipik bir magmatik mineraldir. Diğer taraftan psödolösit, potasyum feldispat, nefelin ve az miktarlarda sodalit, kankrinit veya zeolitten meydana gelen ve lösit kristal yapısı gösteren, hem volkanik ve hem de plutonik kayaçlarda görülen bir kristaller topluluğu olarak tanımlanmıştır (Deer vd., 1965; Lünel ve Akıman, 1985).

Tablo 1. Kimyasal analiz sonuçları

\begin{tabular}{cc}
\hline Ana Oksitler & \% \\
\hline $\mathrm{SiO}_{2}$ & 51.08 \\
$\mathrm{Al}_{2} \mathrm{O} 3$ & 22.00 \\
$\mathrm{~K}_{2} \mathrm{O}$ & 10.83 \\
$\mathrm{Fe}_{2} \mathrm{O}_{3}$ & 4.48 \\
$\mathrm{CaO}$ & 4.08 \\
$\mathrm{Na}_{2} \mathrm{O}$ & 4.06 \\
$\mathrm{MgO}$ & 0.83 \\
$\mathrm{TiO}_{2}$ & 0.56 \\
$\mathrm{P}_{2} \mathrm{O}_{5}$ & 0.22 \\
$\mathrm{SrO}$ & 0.18 \\
$\mathrm{MnO}$ & 0.13 \\
$\mathrm{Cl}$ & 0.08 \\
$\mathrm{ZrO}$ & 0.08 \\
$\mathrm{SO}$ & 0.07 \\
$\mathrm{PbO}$ & 0.03 \\
$\mathrm{ZnO}$ & 0.02 \\
$\mathrm{LOI}$ & 1.25 \\
\hline
\end{tabular}

İnceleme alanındaki holokristalin hipidiyamorf tanesel dokuya sahip kayaç, içerisinde psödolösit (lösit+nefelin+ortoklaz), egirin, egirinojit ve opak mineralleri belirlenmiştir (Şekil 5,6). Mafik minerallerde yer yer opasitleşme türü bozunmalar gözlenmiştir. Mineralojik içeriklerine göre birim feldispatoidli kayaçlardan, foidolit kaya grubu içerisinde tanımlanan foid siyenit (lösitit) olarak isimlendirilmiştir. Lösit+nefelin+ortoklaz mineralleri bir araya gelerek özşekilli psödolösit kristallerini oluşturmaktadır. 

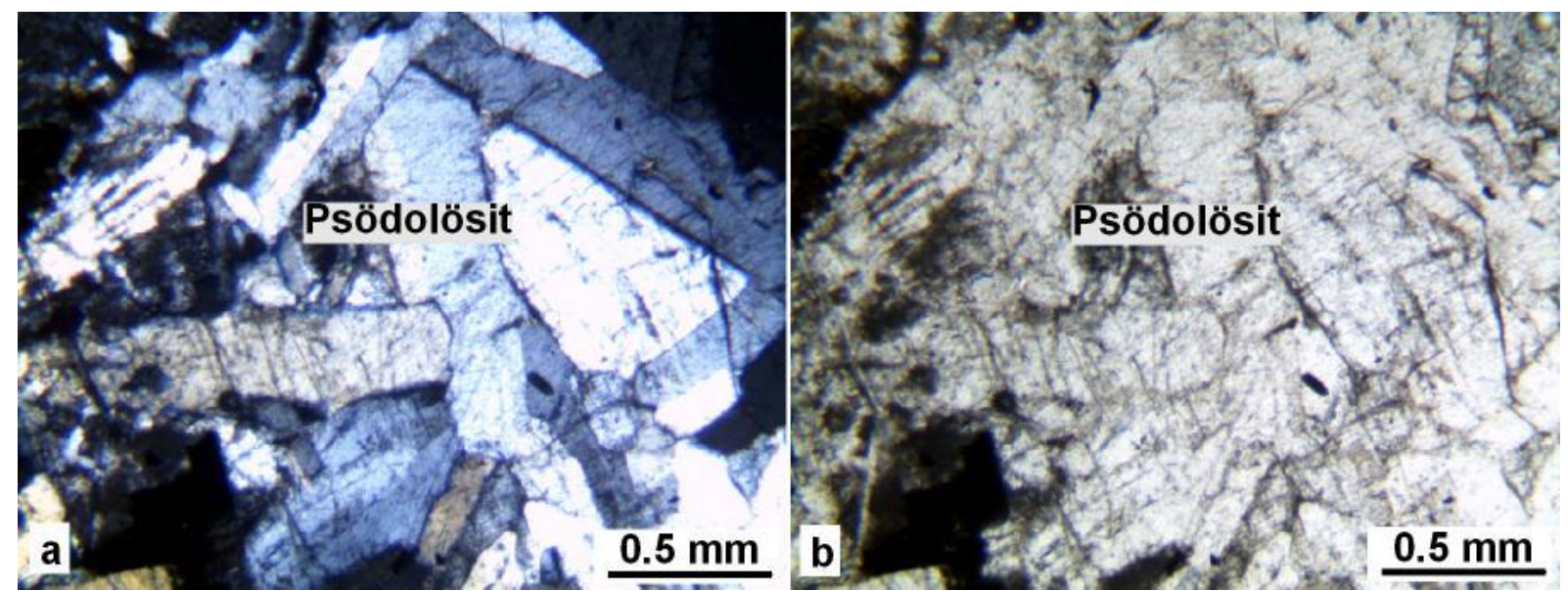

Şekil 5. Lösitit kayacı içerisindeki özşekilli prizmatik lösit mineralleri

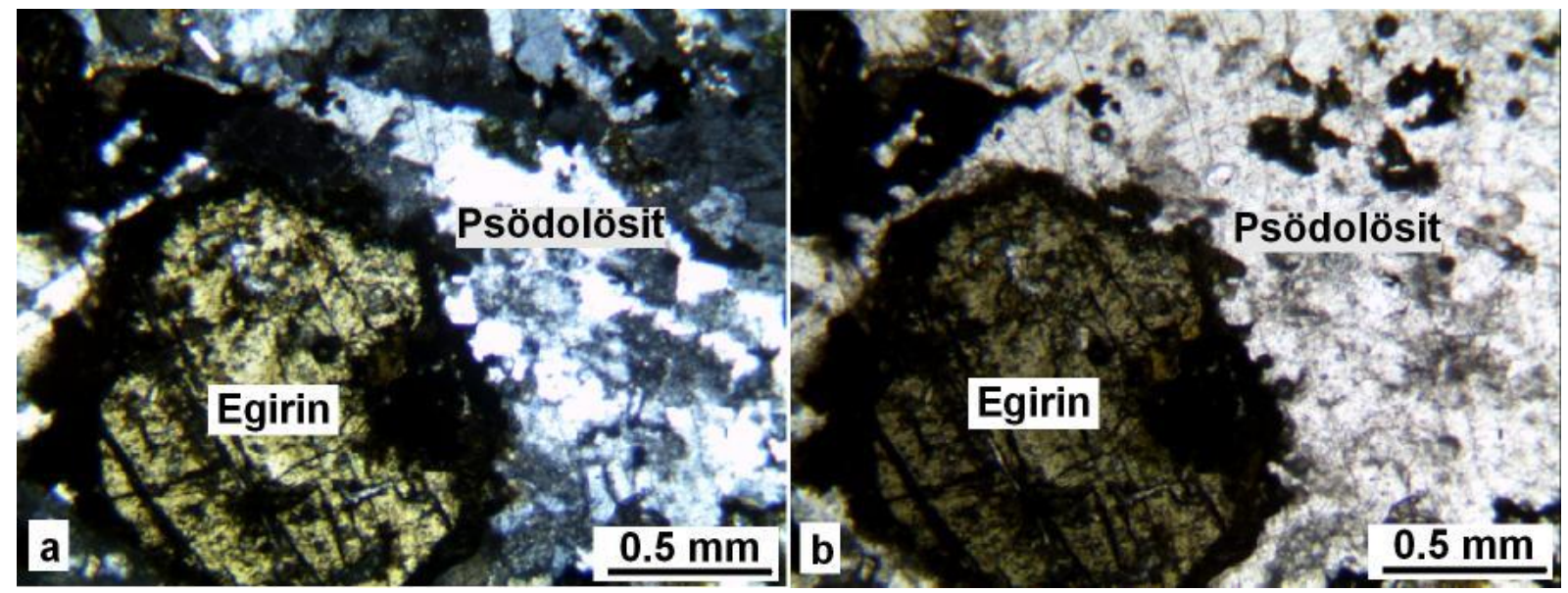

Şekil 6. Lösitit kayacı içerisindeki özşekilli egirin minerali

\subsection{Fiziksel ve Mekanik Özellikler}

Çalışma sahası içerisinde üretim yapılması muhtemel Kırşehir Leopar numunelerinin fiziksel özellikleri TS EN 13755 (2014), TS EN 14157
(2017), ISRM (2007)'e göre ve mekanik özelliklerinden tek eksenli basınç dayanımı da TS EN 1926 (2013) 'ya göre belirlenmiştir. Deneylerden elde edilen sonuçlar Tablo 2' de verilmiştir.

Tablo 2. Fiziksel ve mekanik özelliklere ait deney sonuçları

\begin{tabular}{|c|c|c|}
\hline Deney & Ortalama Değerler & Standartlar \\
\hline Tek Eksenli Basınç Dayanımı Tayini $\left(\mathrm{kgf} / \mathrm{cm}^{2}\right)$ & 1462.3 & TS EN 1926 \\
\hline Birim Hacim Ağırlık (gr/cm³) & 2.63 & TS EN 1936 \\
\hline Ağırlıkça Su Emme (\%) & 0.29 & TS EN 13755 \\
\hline Hacimce Su Emme (\%) & 0.76 & TS EN 1936 \\
\hline Toplam Porozite (\%) & 3.51 & TS EN 1936 \\
\hline Shore Sertliği & 82.69 & ISRM (2007) \\
\hline Böhme Yüzey Așınma $\left(\mathrm{cm}^{3} / 50 \mathrm{~cm}^{2}\right)$ & 7.90 & TS EN 14157 \\
\hline
\end{tabular}

\section{Lösitit'in (Kırşehir Leopar) Yüzey ve Duvar Kaplaması Olarak Kullanılabilirliği}

Kırşehir Leopar taşının yüzey ve duvar kaplaması olarak kullanılabilirliğinin belirlenmesi amacıyla, laboratuvar deneylerinden elde edilen sonuçlar TS 6234 (1988) standardında belirtilen sınır değerler (Tablo 3 ve 4) ile karşılaştırılmıştır. 
Tablo 3. Kaplama taşı olarak kullanılabilirlik için TS 6234 (1988) sınır değerleri

\begin{tabular}{lc}
\hline Deney & TS 6234 \\
\hline Tek Eksenli Basınç Dayanımı Tayini $\left(\mathbf{k g f} / \mathbf{c m}^{2}\right)$ & $>1200$ \\
Birim Hacim Ağırlı $\left(\mathbf{g r} / \mathbf{c m}^{\mathbf{3}}\right)$ & $>2.560$ \\
Ağırlıkça Su Emme (\%) & $<0.75$ \\
Shore Sertliği & - \\
Sürtünme ile Aşınma Kaybı (Böhme) $\left(\mathbf{c m}^{3} / \mathbf{5 0} \mathbf{c m}^{\mathbf{2}}\right)$ & Kaplama taşı için $<15 \mathrm{~cm}^{3} / 50 \mathrm{~cm}^{2}$ \\
& Döşeme taşı için $<10 \mathrm{~cm}^{3} / 50 \mathrm{~cm}^{2}$ \\
\hline
\end{tabular}

Kırşehir leopar kayacının tek eksenli basınç dayanımı, birim hacim ağırlık, ağırlıkça su emme ve sürtünme ile aşınma kaybı değerleri standartta belirtilen sınır değerleri karşılaştırıldı̆̆ında kaplama taşı olarak kullanılabilir olduğu belirlenmiştir (Tablo 4).

Tablo 4. Kırşehir Leopar taşının TS 6234 (1988) standardına göre kaplama ve yapı taşı olarak kullanılabilirliğinin belirlenmesi

\begin{tabular}{|c|c|c|}
\hline Test/Analiz Adı & Ortalama Değerler & Uygunluk Durumu \\
\hline Tek Eksenli Basınç Dayanımı Tayini $\left(\mathbf{k g f} / \mathrm{cm}^{2}\right)$ & 1462.30 & Uygun \\
\hline Birim Hacim Ağırlık (gr/cm³) & 2.630 & Uygun \\
\hline Ağırlıkça Su Emme (\%) & 0.29 & Uygun \\
\hline Hacimce Su Emme (\%) & 0.76 & \\
\hline Shore Sertliği & 82.69 & - \\
\hline Sürtünme ile Aşınma Kaybı (Böhme) $\left(\mathrm{cm}^{3} / 50 \mathrm{~cm}^{2}\right)$ & 7.90 & Uygun \\
\hline
\end{tabular}

\section{Lösit'in (Kırşehir Leopar) Yüzey ve Duvar Kaplaması Uygulama Örneği}

Lösit (Kırşehir Leopar) duvar kaplama, zemin döşeme ve şömine gibi dekoratif yapılarda kullanılabilecek farklı bir ürün olup çalışma kapsamında araziden alınan iri kaya numuneleri fabrika ortamında kesme paralatma işlemlerine tabi tutularak örnek plaka elde edilmiştir (Şekil 7).

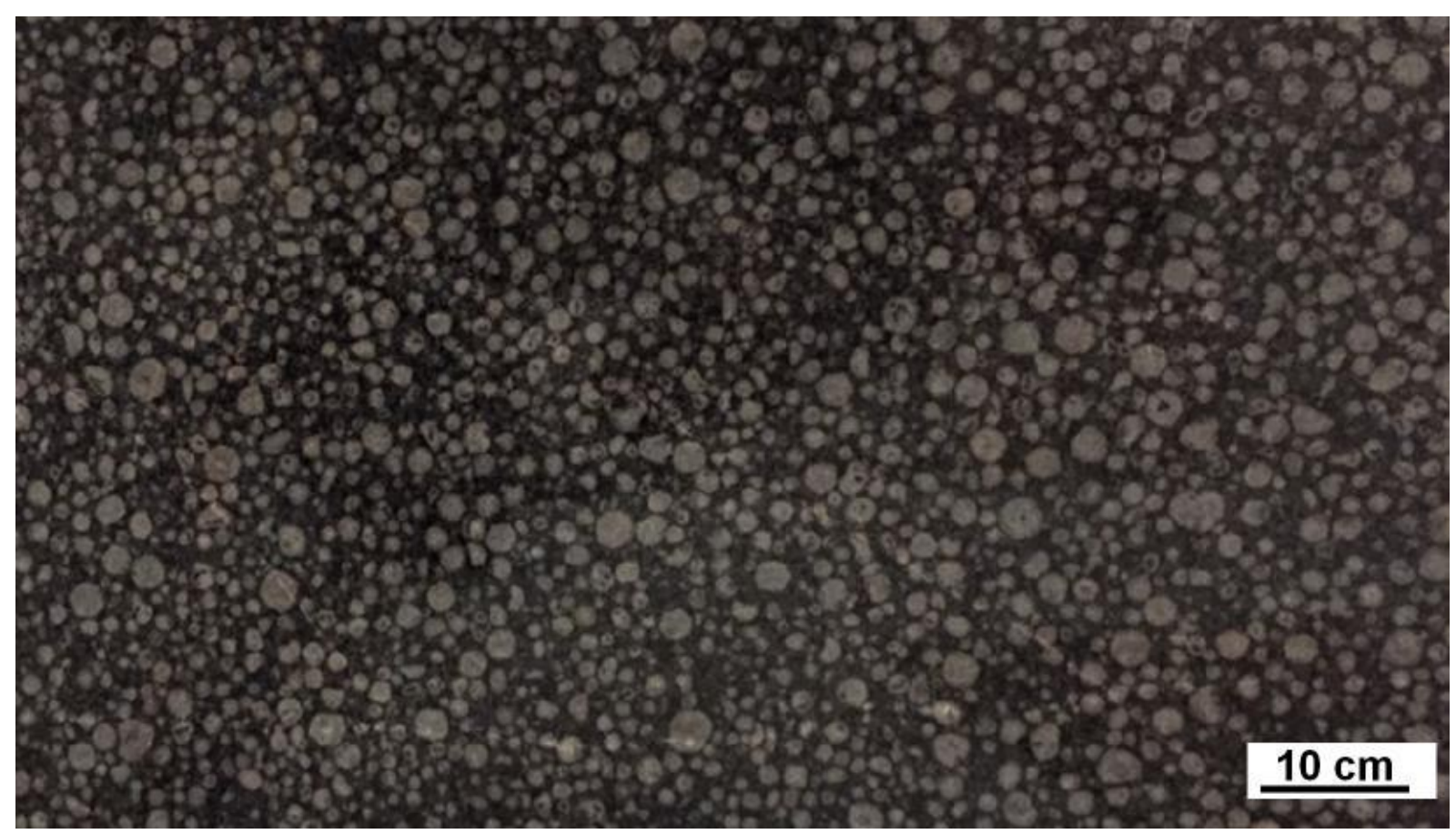

Şekil 7. Lösit (Kırşehir Leopar) numunesine ait parlatılmış plaka görünümü 
Elde edilen plaka görseli sketchup programı kullanılarak merdiven basamağı, riht ve duvar kaplama uygulamalarında ülkemizde yoğun olarak bulunan gri renkli granit örneği ile kombin çalışması yapılmış olup üretimi gerçekleştirilmesi halinde uygulanmasi muhtemel alanlardaki döşenmiş hali tasarlanmıştır (Şekil 8).
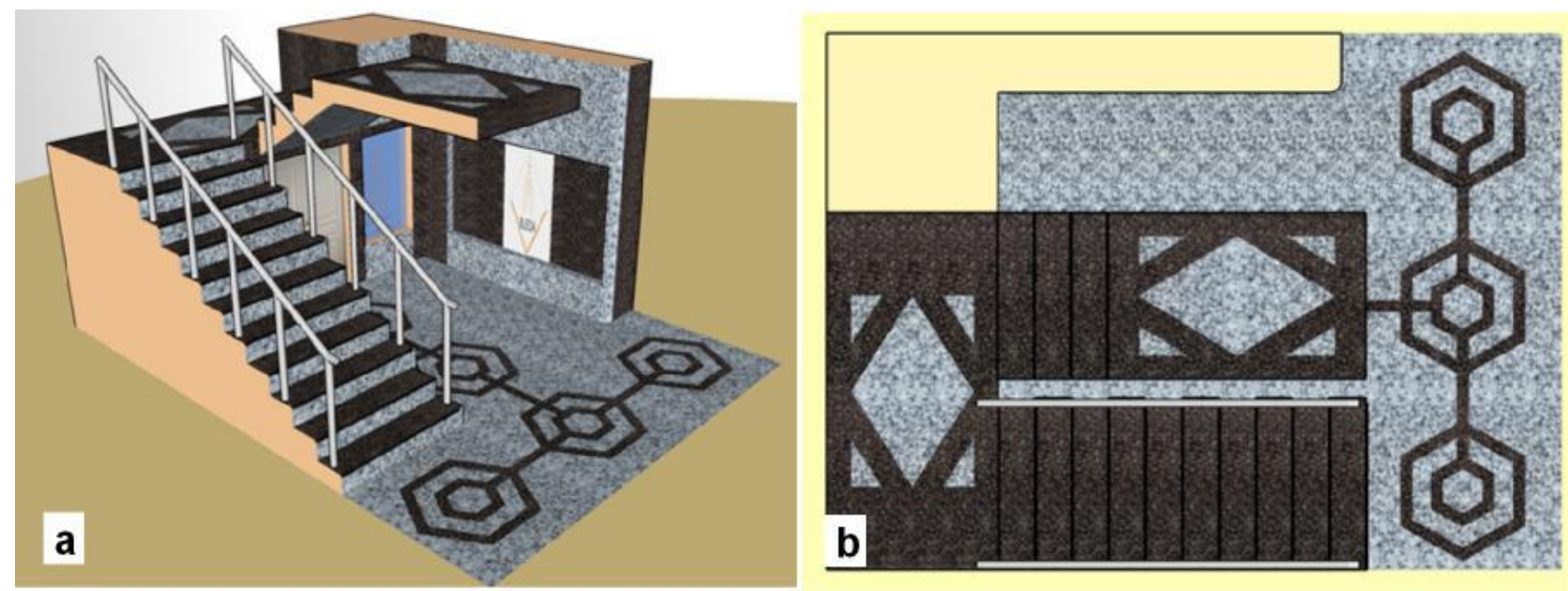

Şekil 8. Lösititin (Kırşehir Leopar) merdiven, duvar ve zemin kaplaması tasarımı (a: genel görünüm, b: üsten görünüm)

\section{Sonuçlar}

İnceleme sahasinda koyu rengi ve kendine has leopar dokusu bulunan foidolit kaya grubu içerisinde tanımlanan lösitit, dünyada nadir olarak gözlenen bir magmatik kayaçtır. Üst KretasePaleosen yaşlı Orta Anadolu Granitoyidleri içerisinde bulunan lösitit kayacı, yüzeysel ve hidrotermal alterasyondan pek fazla etkilenmemesi, tek eksenli basınç dayanımı, birim hacim ağırlık, ağırlıça su emme ve sürtünme ile aşınma kaybı değerleri standartta belirtilen sınır değerleri karşıladığı değerlendirildiğinde "Kırşehir Leopar" kayacının kaplama taşı olarak kullanılabilir olduğu görülmüştür.

Ülkemizde üretimi gerçekleştirilen granitler çoğunlukla gri renkli olup, iç ve dış piyasada yaygın olarak kullanılanları; Aksaray Yaylak, Bulancak Füme, Bergama Gri ve Hisar Gri'dir. Bahsi geçen ticari değere sahip ülkemiz granitleri, renk çeşitliliği bakımından oldukça sınırlı kalmaktadır. TCTB (2018) doğal taş sektör raporundaki verilere bakıldığında, 2017 granit ihracat geliri blok bazında 5,18 milyon dolar, işlenmiş granit bazında 5,34 milyon dolarlık ihracat geliri oluşturmuştur. 2017 granit ithalat değerlerine baktığımızda ise blok granit bazında 2,8 milyon dolar, işlenmiş granit bazında 144 milyon dolardır. Granit ihracat geliri yaklaşık 10 milyon dolar iken ithalat değeri 147 milyon dolar olup 137 milyon dolarlık oldukça yüksek bir fark oluşmaktadır. Bu farkın en önemli nedeni renk ve doku çeşitliğinin ülkemizde sınırlı olmasından kaynaklanmaktadır. $\mathrm{Bu}$ nedenle ülkemiz granit ticari potansiyelinin artırılması noktasında renk ve doku çeşitliliğinin arttırılması önem arz etmektedir. Lösitit kayac1, koyu renk tonu ve leopar benzeri dokusu nedeni ile oldukça dikkat çekici bir doğal taştır. Kırşehir bölgesi lösitilerinin üretime kazandırılması ile doğal taş sektör ürün portföyünde farklı renk ve dokuda kayaç kazandırılarak hem bölge hem de ülke ekonomisine katkı sunacağı düşünülmektedir.

Ayrıca atık malzemenin olumsuz çevresel etkilerinin azaltılmas1 hem de endüstriyel hammadde olarak ekonomiye kazandırılması açısından, blok üretimi sırasında açığa çıkacak pasadan, lösititlerin kimyasal analizleri dikkate alındığında yüksek miktarda $\mathrm{K} 2 \mathrm{O}+\mathrm{Na} 2 \mathrm{O}$ $(\% 10,83+4,06)$ içeriğine sahip olması nedeni ile lösitlerin zenginleştirilmesi sonucunda elde edilecek ürünün seramik, çimento vb. alanlarında endüstriyel hammadde olarak kullanılabileceği öngörülmektedir. Aynı zamanda özgün bir alan olan diş porseleni üretiminde Özkan (2005) tarafindan yapılan çalışmada bölgedeki lösitlerin kullanılabileceği belirlenmiştir.

Çalışma kapsamında elde edilen sonuçlar bölgedeki lösititlerin hem doğal taş hem de endüstriyel hammadde olarak kullanilabilir olduğunu göstermiştir. Bu çalışma ile bölgeye yatırım yapmayı planlayan yatırımcilara, saha hakkında önemli veriler sunulmaktadır. Çalışma 
sahasında gerçekleştirilecek madencilik faaliyetleri ile bölge ve ülke ekonomisine önemli katkılar sunulabileceği düşünülmektedir.

\section{Teşekkür}

$\mathrm{Bu}$ çalışmanın gerçekleştirilmesinde desteklerinden dolayı BLEDA AŞ'ye teşekkür ederiz.

\section{Kaynaklar}

Boztuğ, D., Güney, Ö., Heizler, M., Jonckheer, R. J., Tichomirowa, M., Otlu, N. 2009. 207Pb$206 \mathrm{~Pb}, 40 \mathrm{Ar}-39 \mathrm{Ar}$ and Fission-Track Geothermochronology Quantifying Cooling and Exhumation History of the Kaman-Kırşehir Region Intrusions, Central Anatolia, Turkey. Turkish Journal of Earth Sciences, 18(1), 85108.

Deer, W.A.; Howie, R.A. ve Russman, J., 1965, Rock Forming Minerals: Longmans, London.

Erler, A. ve Bayhan, H., 1995. Orta Anadolu Granitoidlerinin Genel Değerlendirilmesi ve Sorunları. Yerbilimleri, 17, 49-67.

ISRM, 2007. Rock Characterization, Testing and Monitoring -ISRM Suggested Methods. Brown, E.T. (ed), Pergamon Pres, 211p.

Kara, H. Dönmez, M. 1990. 1:100.000 ölçekli açınsama nitelikli Türkiye jeoloji Haritalarıserisi, Kırşehir-G 17 paftası. MTA yayınları.

Lünel, A. T., Akman, O., 1985. Hamitköy, Kaman, Kırşehir bölgesinde bulunan psodolosit oluşuğu ve basınç göstergesi olarak kullanımı. Maden Tetkik ve Arama Dergisi, 103(103,104).

Otlu, N., 1998. Kortundağ-Baranadağ Arası (D Kaman, KIRŞEHIR) Plütonik Kayaçlarının Petrolojik
İncelenmesi. Cumhuriyet Üniversitesi Fen Bilimleri Enstitüsü.

Otlu, N., Boztuğ, D., 1998. The coexistence of the silica oversaturated (ALKOS) and undersaturated alkaline (ALKUS) rocks in the Kortundağ and Baranadağ plutons from the Central Anatolian alkaline plutonism, E Kaman/NW Kırşehir, Turkey. Turkish Journal of Earth Sciences 7, 241-257.

Özkan, M., 2005. Lösit ve Nefelin Siyenitin Değerlendirilmesi ve Diş Porseleni Yapımı. Yüksek Lisans Tezi, Erciyes Üni. Fen Bil. Enst. Kayseri, 91s.

Seymen, İ. 1981. Kaman (Kırşehir) dolayında Kırşehir masifinin stratigrafisi ve metamorfizması. TJK Bült., 24, 2, 101-108.

Taşlıgil, N., \& Şahin, G., 2016. Yapı Malzemesi Olarak Kullanılan Türkiye Doğal Taşlarının İktisadi Coğrafya Odağında Analizi. Marmara Coğrafya Dergisi, 33, 607-640.

TCTB, 2018. Doğal Taşlar Sektör Raporu. T.C. Ticaret Bakanlığı İhracat Genel Müdürlüğü Maden, Metal ve Orman Ürünleri Dairesi, 8s. Ankara.

TS 6234, "Granit Yap1 ve Kaplama Taşı olarak Kullanılan”, TSE, Ankara. 1988

TS EN 13755, 2014. Doğal Taşlar -Deney yöntemleriAtmosfer basincinda su emme tayini. Türk Standartları Enstitüsü, Ankara.

TS EN 14157, 2017. Doğal taşlar -Deney yöntemleriAşınma direncinin tayini. Türk Standartları Enstitüsü, Ankara.

TS EN 1926, 2013. Doğal taşlar -Deney yöntemleriTek eksenli basınç dayanım tayini. Türk Standartları Enstitüsü, Ankara. 